\title{
CHRONOGENETIC STAGING OF TENSE IN RUHAYA
}

\author{
John Hewson and Derek Nurse \\ Memorial University of Newfoundland \\ Henry Muzale \\ University of Dar es Salaam
}

\begin{abstract}
The paradigm of tense and aspect contrasts in Ruhaya, an eastern Bantu language, shows considerable regularity, indication of an ordered system of contrasts. The examination of what appear to be anomalies in the system of contrasts leads to a refinement in the analysis: to the recognition of a tense system that is organised in two stages, based on a model proposed by Gustave Guillaume. Aspectual contrasts are prioritized at the first stage, tense contrasts at the second. Compound forms, which are typically combinations of Stage $2+$ Stage 1 (in that order), are complex representations that are marked for both tense and aspect.
\end{abstract}

\section{Introduction}

This article is the continuation of several strands of research. It examines details of an earlier survey of tense and aspect data in Ruhaya ${ }^{1}$ [Nurse \& Muzale 1999], the results of which are presented in Table 1. It also brings to the Ruhaya data insights from an analysis of tense and aspect in Swahili [Hewson \& Nurse 2001], the results of which are presented in Figure 1 (p. 39). The research on Swahili was in turn an extension of a survey of the tense aspect systems of all the Indo-European language families from prehistory to the present day [Hewson \& Bubenik 1997], based on theoretical proposals stemming from Gustave Guillaume [1929, 1945, 1964, 1971-2000]. We include a few brief comments on our earlier paper on Swahili because of its theoretical and typological relevance to the questions we raise concerning Ruhaya.

In this work, verbal systems are seen as stratified systems of representation that are cognitively grounded, in which the more complex representations are secondary developments, built on a base of earlier less complex forms of representation.

1 The prefix $\mathrm{Ru}$ - on the name of the language has been retained in deference to the usage of native speakers. For them, removing the prefix renders the stem meaningless. We have kept Swahili, however, since this form has now become the universally accepted usage for English. 
Table 1: The verbal paradigm of Ruhaya.

\begin{tabular}{|c|c|c|}
\hline Aspect $\Rightarrow$ & $\begin{array}{l}\text { Performative } \\
\text { (Simple) }\end{array}$ & $\begin{array}{l}\text { Habitual } \\
\text { /-aga/ }\end{array}$ \\
\hline $\begin{array}{c}\text { FAR PAST } \\
\text { /-ka-/ }\end{array}$ & $\begin{array}{l}\text { tú-ka-gura } \\
\text { We bought }\end{array}$ & \multirow[t]{3}{*}{$\begin{array}{l}\text { tu-a-gur-âga } \\
\text { We used to buy }\end{array}$} \\
\hline $\begin{array}{l}\text { NEAR PAST (Mid Past) } \\
/-\emptyset-/+/ \text {-ire/ }\end{array}$ & $\begin{array}{l}\text { tu- } \varnothing \text {-guz-îre } \\
\text { We bought }\end{array}$ & \\
\hline $\begin{array}{l}\text { MEMORIAL PRESENT } \\
\text { (Near Past) /-á(á)-/ }\end{array}$ & $\begin{array}{l}\text { tu-áá-gura } \\
\text { We bought }\end{array}$ & \\
\hline $\begin{array}{l}\text { EXPERIENTIAL PRESENT } \\
\text { (Present) } /-\emptyset-/\end{array}$ & & \multirow[t]{2}{*}{$\begin{array}{l}\text { tu- } \varnothing \text {-gúra } \\
\text { We buy }\end{array}$} \\
\hline $\begin{array}{c}\text { NEAR FUTURE } \\
\text { /-raa-/ } \\
\end{array}$ & $\begin{array}{l}\text { tu-raa-gúra } \\
\text { We will buy }\end{array}$ & \\
\hline $\begin{array}{c}\text { FAR FUTURE } \\
/ \text {-ri-/ }\end{array}$ & $\begin{array}{l}\text { tu-ri-gúra } \\
\text { We will buy }\end{array}$ & $\begin{array}{c}\text { tu-raa-gur-âga } \\
\text { We will buy regularly }\end{array}$ \\
\hline
\end{tabular}

The normal referential scope of the tenses is as follows:

1. Far Past: before yesterday.

2. Near Past: yesterday.

3. Memorial Present: earlier today.

4. Experiential Present: a vast, extended present.

5. Near Future: later today and tomorrow.

6. Far future: after tomorrow. Variations may be caused by the lexical meaning of the verb.

The forms given in this table are segmentally underlying but tonally surface. Various rules assign tones to tense/aspect forms. For instance, the verb / ku-gura/ 'to buy' is underlyingly low, but all the forms given in the table above are marked by a high or falling tone; these tonal patterns would change if a high toned verb like /ku-kóma/ $\rightarrow$ [kukôma] 'to tie up' is used. The analysis of tone, however, is beyond the scope of this paper; for further details on tone, see Hyman \& Byarushengo [1984].

The formative /-ire/ changes the final /r/ of the radical /-gur-/ to [ $\mathrm{z}$ ], hence, [-guz-]. This formative has more aspectual functions in the verbal system than are covered in this paper. For further analysis of the various functions of /-ire/ and how it combines with other formatives such as /-a(a)-/, /-ka-/, and /-ra-/, see Muzale [forthcoming]. 


\begin{tabular}{|c|c|c|}
\hline $\begin{array}{c}\text { Progressive } \\
\text { /ni-/ }\end{array}$ & $\begin{array}{l}\text { Retrospective } \\
\text { /-áá-/ + /-ire/ }\end{array}$ & $\begin{array}{c}\text { Persistive (Still) } \\
\text { /-ki-áá-/ }\end{array}$ \\
\hline $\begin{array}{l}\text { tú-ka-bá ni-tu-gúra } \\
\text { We were buying }\end{array}$ & $\begin{array}{c}\text { tú-ka-ba tu-áá-guz-ire } \\
\text { We had bought }\end{array}$ & $\begin{array}{l}\text { tu-ka-bá tu-kiáá-gura } \\
\text { We were still buying }\end{array}$ \\
\hline $\begin{array}{l}\text { tu-ba-ire ni-tu-gúra } \\
\text { We were buying }\end{array}$ & $\begin{array}{l}\text { tu-ba-ire tu-áá-guz-ire } \\
\text { We had already bought }\end{array}$ & $\begin{array}{l}\text { tu-ba-ire tu-kiáá-gura } \\
\text { We were still buying }\end{array}$ \\
\hline $\begin{array}{l}\text { tu-aa-ba ni-tu-gúra } \\
\text { We were buying }\end{array}$ & $\begin{array}{l}\text { tu-aa-ba tu-áá-guz-ire } \\
\text { We had already bought }\end{array}$ & $\begin{array}{l}\text { tu-aa-ba tu-kiáá-gura } \\
\text { We were still buying }\end{array}$ \\
\hline $\begin{array}{l}\text { ni-tu- } \varnothing \text {-gúra } \\
\text { We are buying }\end{array}$ & $\begin{array}{c}\text { tu-áá-guz-ire } \\
\text { We have already bought }\end{array}$ & $\begin{array}{c}\text { tu-kiáá-gura } \\
\text { We are still buying }\end{array}$ \\
\hline $\begin{array}{l}\text { tu-raa-ba ni-tu-gúra } \\
\text { We will be buying }\end{array}$ & $\begin{array}{c}\text { tu-raa-ba tu-áá-guz-ire } \\
\text { We will have already bought }\end{array}$ & $\begin{array}{l}\text { tu-raa-ba tu-kiáá-gura } \\
\text { We will still be buying }\end{array}$ \\
\hline $\begin{array}{l}\text { tu-ri-ba ni-tu-gúra } \\
\text { We will be buying }\end{array}$ & $\begin{array}{c}\text { tu-ri-ba tu-áá-guz-ire } \\
\text { We will have already bought }\end{array}$ & $\begin{array}{l}\text { tu-ri-ba tu-kiáá-gura } \\
\text { We will still be buying }\end{array}$ \\
\hline
\end{tabular}

Near Future /-raa-/ contrasts with (short-vowelled) /-ra-/, which is a second Retrospective (see Nurse [1979: 12-13], Nurse \& Muzale [1999: 542], and Muzale [forthcoming: section 4.5.5]).

Far Past is represented by $/-\mathrm{a}-/$ in the Habitual but by $/-\mathrm{ka}-/$ in the other categories. This asymmetry occurs in other Lacustrine languages, especially in the Rutara languages, Ruhaya's nearest relatives [Muzale, forthcoming: Appendices].

Vowel length in the Far Past (Habitual), the Memorial Present, and the Retrospective is a vexing issue. Since Ruhaya lengthens vowels after consonant + glide, underlying contrasts such as $/ \mathrm{tu}+\mathrm{aa} . . . /$ and $/ \mathrm{tu}+\mathrm{a} . . . /$ are neutralized on the surface as [twaa...]. The markers for these three forms occur exclusively after consonant + glide, so the evidence for the underlying forms is largely tonal (see Muzale [forthcoming].) 
This development of a linguistic time-image in successive stages was called chronogenesis by Guillaume. Typically in such systems, aspectual contrasts are developed before tense contrasts, which normally arise at the last stage of chronogenesis. What is particularly interesting for the Swahili and Ruhaya data (and for tenses in other Bantu languages) is that tense, in the Guillaumian model, is developed at two successive stages, giving rise to complex systems that are typologically different from those of Indo-European languages.

The terms develop and stages are usually used in a diachronic sense, whether used of linguistic evolution or language acquisition. In this work, they are used to indicate the parameters of a cognitive system of representation, a permanent mental reality that is part of the acquired mental linguistic capacity of the native speaker. ${ }^{2}$ Guillaume, like Jakobson [1968, 1971, 1990: 297ff], sees linguistic systems as being stratified: Jakobson, for example, claims that systemic elements that are learned last in childhood and lost first in aphasia are necessarily-based on other primitive, fundamental elements learned early and maintained in partial aphasias. Guillaume, for his part, sees verbal systems as stratified, as involving stages of mental processing, building complex representations out of simpler, more basic representations.

\section{The verbal paradigm of Ruhaya}

In Table 1, the fundamental representational contrasts of the Ruhaya verb are laid out paradigmatically, using terminology that has mostly been traditional in analysing Bantu languages. ${ }^{3}$ The paradigm was prepared by listing what appeared to be tense contrasts vertically, and apparent aspectual contrasts horizontally, basing categories partly on function and partly on morphosyntax. This paradigm is not the result of our analysis, but its point of departure.

Neither the presentation in Table 1 nor the accompanying discussion includes all the paradigmatic forms of Ruhaya. A completed conjugation would include not just the affirmatives presented here but also negatives, relatives, conditionals, other modals, and other (dependent) forms such as consecutive. Our focus is the tenseaspect system of main clauses. The maximum number of tense-aspect contrasts in Ruhaya, as in most Bantu languages, occurs in affirmative forms; that is our reason for not including the other Ruhaya forms, many of which can be found in, for example, Byarushengo et al. [1976], Byarushengo et al. [1977], Dalgish [1977], Muzale [forthcoming], Nurse [1979], Nurse \& Muzale [1999], Saloné [1977].

2 Although such a staged system is normally acquired in stages, so that acquisition studies show the quasi universal acquisition of aspect before tense in child language (see Fletcher [1985:120] and the references he quotes), we are not immediately concerned with acquisition, but with the system acquired, which has its own representational stages.

3 The obvious exceptions are Performative and Retrospective, terms borrowed from Hewson $\&$ Bubenik [1997], and reviewed in Section 3.2 and fn. 8. A Performative is similar in function to a Perfective, but with a distinctively different distribution. A Retrospective (after the event) is traditionally a Perfect (sometimes Anterior today); the term was deliberately chosen to avoid confusion (e.g., Perfect / Perfective) and to form a balanced pair with Prospective (before the event). 
There is occasionally a discrepancy between some forms here and their shape as cited elsewhere. We feel confident that our forms for the dialect used here are correct, as one of the co-authors is both linguist and speaker of this dialect. Readers should consult Muzale [forthcoming] for further details.

Using this basic taxonomic statement as a point of departure, an extended analysis brings into focus certain important questions. As Heine has noted [1993:121]: "A grammar ... that is not confined to description but aims at explaining linguistic structure" has to ask why certain forms are used in certain functions. We intend to examine the following questions.

(1) Why does the unmarked form $t u-\emptyset$-gúra have its own separate column? (The forms with -aga in the same column appear to be relics of an earlier aspectual system in which this suffix marked iteratives: the paradigm of /-aga/ has disappeared except for these two forms. We say they are relics because data from other Lacustrine languages (e.g., Luganda) in general have -aga co-occurring with tenses more widely than in Ruhaya. We interpret this to mean that -aga has been, and is being, progressively replaced in Ruhaya. We present it as one unanalyzed morpheme, rather than more than one morpheme, because of the existence of alloforms such as -age and -ega in some subjunctives/futures. ${ }^{4}$ )

(2) Why does the form $t u-\emptyset$-guz-îre, that has no segmental tense marker (immediately after the subject marker /tu-/), appear in the first column? Is the suffix -ire an aspect marker like the -aga of the relics? A form that marks a contrastive tense should be found only in the horizontal parameters of the paradigm (otherwise it would not be contrastive). But the only marker on this form, the /-ire/ suffix, is also found vertically, in the Retrospective column, indicating some kind of a contradiction: an aspectual form having a tense-like function in certain contexts. In terms of its form and its distribution -ire is not a tense formative.

(3) If -ire is an aspect marker (synthetic aspect: marked within the word), there is obviously a second aspectual system (analytic, marked periphrastically). Is there a connection between the two types?

(4) Why do the two forms (tugúra and tuguzîre) also appear in the aspect columns, one with a prefixed particle $n i$, the other with a marker -áá-, which resembles that of the Memorial Present? What is the difference, for example, between tuguzîre and tuááguzire?

(5) Why do the aspectual forms tuááguzire (Retrospective) and tukiáágura (Persistive) both have, in post-subject position, markers (-áá-, -kiáá-, respectively) which are clearly not tense markers, since these forms can be used with all tenses? If they are aspectual markers, what kind of aspectual markers are they?

The remainder of this article is dedicated to the clarification of these questions.

4 It should be noted that the tense markers of these forms are for the Memorial Present (/-á(á)-/) and the Near Future (/-raa-/), respectively, creating a pair of generalized Past and Future iteratives, which correspond more or less with the semantic value that is also found in tugúra, as will be explained in Section 5. 


\section{Principles of analysis}

In the analysis of Swahili mentioned in the introduction, the peculiarities of the paradigmatic and distributional data led us to postulate a tense system with two stages, one where aspectual contrasts were developed in forms that had no tense markers but were used nevertheless as forms representing a vast, undifferentiatied present time (i.e., a present with no tense contrasts), and a second stage where tense contrasts were developed. This analysis was based on the fact that the forms of the Vast Present had no mark of tense, but could be marked for aspect, whereas the forms that were marked for tense could not be marked for aspect, aspectual forms for such tenses being created by compounds in which the marked tense was in the auxiliary, and the aspectual form in the main verb, both forms finite, as in Ruhaya aspectual forms (except for the Experiential Present) in Table 1.

The two stage chronogenetic system of Swahili was established as in Figure 1, with the aspectual contrasts of Stage 1 presented vertically, and the tense contrasts of Stage 2 presented horizontally. It should be noted that all the arrows at Stage 1 point to the left (representations of events in Descending Time), whereas the two arrows at Stage 2 point to the right (representations of Events in Ascending Time). A brief discussion of the terms tense, aspect, Ascending Time and Descending Time will clarify the nature of these linguistic contrasts.

3.1 Tense and aspect. Tense and aspect are defined by Guillaume [1933/1964: 478] as follows: aspect is the representation of the time contained by the event; tense is the representation of the time that contains the event. An illustrative analogy: aspectual forms concern different views of the ship on the ocean as it passes (from ahead, the bow, amidships, the stern, from behind); tense is the particular ocean on which the ship floats (e.g., Atlantic vs. Pacific). This corresponds in general terms to definitions proposed by others (e.g., Comrie [1976, 1985]; Dahl [1985]). Guillaume's terms were updated and simplified by Valin [1965, 1975], so that today we say that aspect represents Event Time, whereas tense represents Universe Time (capitals indicate mental representations). Cognitively, tense is always in relation to the consciousness of the speaker and hearer: the past originates as time that is in the memory, the future as time that is in the imagi-nation: speakers, for example, may represent an event as being in memorial time (past) or in imaginary time (future), or experiential time, time that is coeval with consciousness (present).

3.2 Descending and Ascending Time (again, capitals for mental representations). This contrast has been discussed by many linguists [Benveniste 1965, Fillmore 1975, Traugott 1978, Lakoff \& Johnson 1980] using such terms [Clark 1973:35] as "moving world" (= D(escending) T(ime)) vs. "moving ego" (= A(scending) T(ime)) or "moving time" vs. "moving ego" [Fleischman 1982:324]. Guillaume [e.g., 1937/1964:60] uses the cognitive contrast of (a) time that works in the mind (Descending Time), automatically recording the stream of consciousness, and as the record progresses into the past, burying our sensory experience ever deeper in the memory as it accumulates further memory on top of it, and (b) the mind that works in time (Ascending Time), involved in conative or imaginary activity (such 
Figure 1. The two chronogenetic stages of the Swahili verbal system.

Stage I

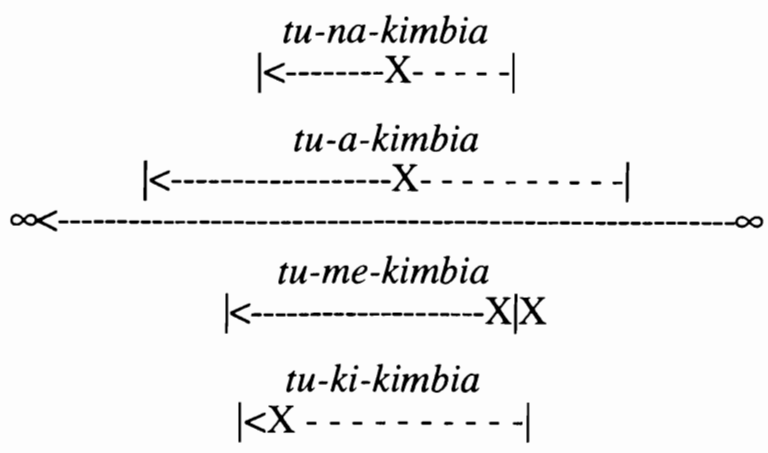

Stage II

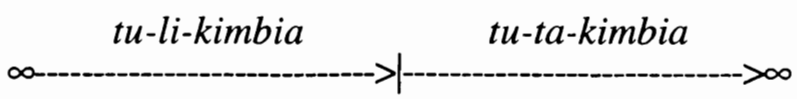

1. The verb is kukimbia "to run"; all finite forms are given with 1P subject $t u$-.

2. Stage I presents the four aspectual forms of the unlimited present. The /na-/ and /a-/ forms are both Imperfective, i.e., temporally incomplete 5 ; $m e$ - is Retrospective; ki- Potential. 6

3. Stage II presents the two contrastive tenses, past (li-) and future (ta-).

as the writing of a paper), where the activity progresses from the present into the future in complete units, such as sentences or paragraphs. The imagination, that works in Ascending Time, is goal oriented: the planning of a sentence or paragraph requires a goal.

The representations in Descending Time give us the internal view of an event: the view that we get when a strip of film runs in the projector (time moves). Those of Ascending Time give us the external view of an event: the view that we get when the strip of film is held in the hand (time is static, but the film still stores the representation of the event). These two representations correspond cognitively to the operations of the working memory (short-term) and the stored memory (long term). We can "replay" the working memory, and repeat a sentence exactly as it

5 Standard Swahili and (coastal) dialect Swahili differ with respect to the use of /-na-/ and /-a-/. We outline briefly here usage in Standard Swahili. The situation in Standard Swahili is changing away from /-a-/ towards /-na-/. Some speakers use only /-na-/, some use the two interchangeably, others distinguish them. In the latter case, /-na-/ tends to be used with dynamic verbs, to represent an event taking place at or around the moment of speech/reference, whereas /-a-/ is used more with stative verbs, to represent a longer time period. See Contini-Morava [1987] and Wald [1997]. 6 Potential is not to be confused with imaginary. The water stored behind a dam in a hydroelectric system is potential energy: real energy, just waiting to be released. Potentials have a variety of functions: sometimes the representation is similar to a modal, sometimes similar to an imperfective or progressive. 
was said with intonation patterns and tone of voice. A week later we may remember that we did this, but the stored memory does not give us a replay. The contrast is similar to that of mass (internal) vs. count (external) in the noun paradigm. There are three common aspects that are representations in Descending Time, as follows, with traditional Indo-European terminology on the left, and our own terminology on the right, based on the usage of Slavic aspectologists, using Imperfective, Perfective to replace imperfect and aorist, and Retrospective to replace the potentially confusing term perfect, which is not to be confused with Perfective (see fn. 14, Section 5).

(6) imperfect

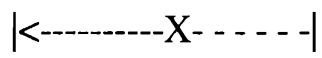

Imperfective

(7) aorist

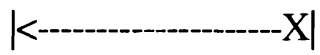

Perfective

(8) perfect

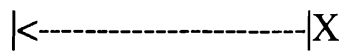

Retrospective

We may illustrate these contrasts from English where (9)-(11) exemplify (6)-(8), respectively. 7

(9)

(10)
We saw the rope breaking.

We saw the rope broken.

We found the rope broken.
(Imperfective)

(Perfective)

(Retrospective)

The contrast between Perfective and Retrospective is slight: it amounts to positions on opposite sides of the same threshold, and frequently a single form covers both functions, as in (10) and (11). ${ }^{8}$ The /me-/ perfect of Swahili, the perfects of French and German, for example, are freely used in both functions. In English, verbs of perception will require the event of broken to be contemporaneous (and therefore Perfective), whereas found requires broken to be interpreted as representing the resultant state of the event (and therefore Retrospective).

The frequency of occurrence of Imperfective, Perfective, and Retrospective in the world's languages stems from the fact that they are representations of universal cognitive experiences: $(9)=$ ongoing perception, following an event in progress; (10) = recognition of the completion of an event (the baby's "all gone"); and $(11)=$ recognition of a resultant state (the broken rope).

Representations in Ascending Time, by contrast, are oriented toward the future, and because they give an exterior view of the event, there is only one simple

7 The examples are participles in English. There are of course languages in which these contrasts occur in finite forms: Ancient Greek égraphon, égrapsa, egegráphe: 'I was writing, I wrote, I had written' (all past), or Kikuyu a-a-hanyok-aga, a-a-hanyok-ire, a-a-hanyok-ete, 'I was running, I ran, I had run' (all Far Past; data from Johnson [1980]).

8 Whereas Ancient Greek had different forms for aorist and perfect, Classical Latin (as the historical morphology shows) had collapsed both to a single form, the perfect, which functioned as both present perfect and aorist. Latin momordi (<mordeo) 'I have bitten, I bit', for example, shows the reduplication typical of the PIE perfect, whereas scripsi $(<$ scribo) 'I have written, I wrote', shows the suffixed /-s/ of the PIE sigmatic aorist. 
representation: a complete event beginning at a moment $X$. Traditionally called simple forms in English grammars (by contrast with the progressive forms), we have given the name Performative to this aspectual representation, because it normally represents the complete performance of an event, or the unchanging nature of a habit or state: He shoots, he scores; he walks to work; I know he owns it.
(12) Simple

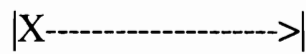
Performative

In systems that are built on Ascending Time, the ordinary tenses will have Performative aspect inherently (unmarked), as does English, and may develop a Progressive aspect as a marked contrast (see above). In systems that are built on Descending Time, the ordinary tenses will have Imperfective aspect inherently, as in Ancient and Modern Greek, and will normally automatically have either a Perfective (aorist) aspect to represent complete events (as does Greek), or a Retrospective (as did Latin). The need for a representation of complete events in Descending Time appears to be greater than the need for a representation of ongoing (i.e., Progressive) events in Ascending Time.

\section{The staged development of tense representations}

In the Swahili verbal system (Figure 1), Stage I is the first level of representations, where all forms represent a single tense, the unlimited present of Universe Time in which there are no tense contrasts. The forms at this level are marked only for aspect: although unmarked for tense all have subjects and may be used as clausal verbs, indicating that they are representations of Universe Time. At Stage II in Swahili this vast present is divided into the contrastive time spheres of Memorial Time (past) and Non-memorial Time (future). The two levels represent two developmental stages: (i) the variations of Event Time (aspectual contrasts) with the first representation of Universe Time at Stage 1; (ii) the variations of Universe Time (tense contrasts) at Stage II.

This analysis establishes certain basic principles of analysis which are relevant to the analysis of other Bantu languages. These principles are as follows.

(13) - the representation of tense is typically developed in two successive stages, a first stage where there are no tense contrasts, ${ }^{9}$ just a single unlimited present, and a second stage where there may be multiple tense contrasts. 10

9 The important word is contrasts, that is, tenses that do not overlap, but stand in complementary distribution to each other, as do the four forms in the first column of Table 1 that have a tense marker in pre-stem position. This would of course exclude tuguzire, which, as the Retrospective column shows, is clearly not contrastive. Where Bantu languages are reported as having many tense contrasts, it is advisable to do a careful survey of the morphological and paradigmatic evidence to make sure that aspectual forms have not been reported as tenses.

10 One author has a database containing tense-aspect analyses of $120 \mathrm{Bantu}$ languages. Only two exceptions (W. Gogo and one Grassfields variety) are reported to have more than four, i.e., five past contrasts. 
(14) - the single indicative forms that are unmarked for tense represent the undifferentiated Universe Time of the unlimited present of Stage I, extending from an infinity in the past to an infinity in the future; the single indicative forms that are distinctively marked for tense are the basic forms of the contrastive tense system of Stage II.

(15) - a single verbal form cannot have more than one tense because it cannot be contained in more than one kind of Universe Time (a ship cannot float on two oceans at once). Consequently, in compounds where two tense-aspect forms occur together in a single verbal representation, the two forms are never both from Stage II. 11 They can both be from Stage I, however (where there are no tense contrasts, only aspects), and there can be combinations of Stage II (in first position) and Stage I (in second position), always in that order. ${ }^{12}$

In these latter combinations, the first form represents the contrastive tense and the second form must be a representation which can overlap, and not contrast, with the tense of the first. The second form, therefore, must necessarily represent the limitless present of Stage I, of which the contrastive tenses of Stage II are, in a sense, hyponyms. Consequently, the representations of Stage I may be used in second position with all the contrastive representations of Stage II because they are consonant with, and not contrastive with, all the forms of Stage II.

It can be seen that these principles apply also to the paradigm of Ruhaya in Table 1. Application of these principles sets in motion a chain of conclusions that resolve, one by one, the questions raised in $\$ 2$ above.

\section{The Separation of Tense Levels in Ruhaya}

The first step in applying the principles laid out in (13)-(15) is to separate the forms tugúra, tuguzîre from the remaining four tense forms in the first column of Table 1, leaving four forms explicitly marked for tense: tú-ka-gura, tu-áá-gura, tu-raa-

11 If two different contrastive tenses occur together, they necessarily represent two different clauses, as in English He said he will come. Although the claim that two purely tense (Stage II) forms cannot co-occur seems simple, it is nevertheless controversial, and our position requires some explanation. We would analyse compounds such as:
Ruhaya
tu-raa-ba twáá-guz-ire
'we will have bought'
Ruhaya
tu-raa-ba twáá-guz-e
'we will have bought'

as both containing an auxiliary verb, marked for (future) tense, followed by the main verb. We see the main verb as being marked only for (retrospective) aspect, by the combination of pre-stem /-aa-/ and suffixed /-ire, -e/. Botne (p.c.) analyzes a comparable form in Kinyarwanda differently, interpreting /-aa-/ in the second verb as a tense marker. Hence, his analysis would allow such compounds to have two tense markers. For more on his position, see Botne [1983, 1986, 1989]. 12 The ordering is probably a cognitive universal: a hypernym may be used anaphorically of a hyponym, but not vice versa. A hypernym, of course, covers the whole meaning of a hyponym, whereas the inverse is not true: He wounded the bear and the animal became enraged vs. ${ }^{*} H e$ wounded the animal and the bear became enraged. A Vast Present (the hypernym) includes both Past and Future, whereas Future and Past, as tenses (the hyponyms), stand in complementary distribution, in contrast to each other. 
gúra, tu-ri-gúra. These will now be analysed as the four tenses of Stage 2 of the chronogenesis of Ruhaya, and tugúra, tuguzîre as aspectual forms from Stage 1 (see Figure 2 below), since they carry no contrastive mark of tense (see (14) above).

The relationship of tugúra and nitugúra (see (4) above) now becomes clear: $n i$ is a focussing or actualizing particle which changes tugúra 'we buy habitually' to nitugúra 'we are buying right now' (Progressive), or 'we have decided to buy, we intend to buy', as in nitugurá emótoka [nitugulé:mótoka] 'we are buying a car (but haven't got it yet)'. This focussing or actualizing particle $n i$ is used extensively in Bantu languages; its cognate $n e$ is used in Kikuyu, for example, to mark assertions as opposed to presuppositions [Johnson 1980:272]; its cognate $n i$ in Swahili is used as a copula.

The relationship between these two forms also casts light on tugúra, which must necessarily be Imperfective, that is, a representation in Descending Time, in order for its focussed form nitugúra to be the representation of an event in progress, a sense which it has throughout the paradigm. ${ }^{13}$ An Imperfective at Stage 1, representing the vast present of Universe Time, would typically have the unfocussed meaning 'we are involved in buying without limitation of time', that is, in ordinary English 'we buy (habitually)'.

It is a quasi-universal that where the basic form in a paradigm is Imperfective, there will also be a corresponding and contrastive form to represent an event that is complete. This normally takes the form of a Perfective (as in Greek or Slavic), but it may also be a Retrospective 14 (as in Classical Latin) or a Performative (as in modern Romance languages), all of which have been explicitly analysed elsewhere [Hewson \& Bubenik 1997]. This is a principle which immediately makes sense of the form tuguzîre: here is the Perfective or Retrospective which corresponds to the Imperfective tugúra: what is already complete in the present must have taken place in the past, typically in the time just before the present. ${ }^{15}$ Like tugúra, it has no tense marking, and it carries the same Perfective marker -ire as the Kikuyu Perfective form a-a-hanyok-ire, quoted in footnote 7 above. There is also other evidence to indicate that tuguzire is, in fact, not a Perfective, but a Retrospective.

\subsection{The status of the /-ire/ suffix. The evidence for analysing the /-ire/ forms of Ruhaya as Retrospective rather than Perfective is threefold.}

13 All that $n i$ changes is the focus; the inherent aspect of the form remains unchanged. The result is an imperfective which is focussed on a given moment: either the here and now, or a moment elsewhere in time defined by the auxiliary.

14 As noted above (3.2), we avoid the term perfect, the usual terminology, in order to eliminate the confusion between perfect and perfective, which are quite different entities. The Perfective simply represents the completion of the event; the Retrospective looks back from the result phase to the complete event.

15 The sense of the Sanskrit aorist (i.e., perfective) was described by Pãnini as adyatana 'recent past' [Bubenik 1997:63], representing an event just completed, much like the 'all-gone' of early child language in English. In Ruhaya, the Memorial Present represents the time that has elapsed since the last sleep, and tuguzîre represents an event completed just before that, i.e., (typically) yesterday. 
(i) Bantu languages share a common trait of using Retrospective forms of stative verbs to represent the present state. Standard Swahili uses the forms in (16) with the Retrospective marker/-me-/ for ordinary present reference. In these forms with $3 \mathrm{~S}$ subject marker $a$-, the resultant state that is represented by the Retrospective aspect becomes the focus of the representation.

(16) amelala

amesimama

ameoa

amekufa

ameamka

amekaa
' $3 \mathrm{~S}$ is asleep (has fallen asleep)'

' $3 \mathrm{~S}$ is standing (has stood up)'

' $3 \mathrm{~S}$ is married (has married)'

' $3 \mathrm{~S}$ is dead (has died)'

' $3 \mathrm{~S}$ is awake (has woken)'

' $3 \mathrm{~S}$ is sitting (has sat down)'

This typical Bantu usage of the Retrospective is found with the Ruhaya suffix /-ire/, as the items in (17) show.
a-nagi-ire
' $3 \mathrm{~S}$ is asleep'
$a$-fi-ire
' $3 \mathrm{~S}$ is dead'

In short, with these verbs of resultant state the form in /-ire/ is not functionally a Near Past (as in Table 1), but a Present, representing the resultant state of an earlier event. This is often a typical Retrospective usage, as may be seen in languages such as French or Latin, where a Retrospective can have both values, with different translations into English.
FRENCH
il est mort
il est mort
il est parti
il est parti

LATIN

mortuus est

mortuus est

profectus est

profectus est

\section{ENGLISH}

'he died' (preterit)

'he is dead' (present reference)

'he left' (preterit)

'he's gone' (present reference)

From these examples it can be seen that, in French and Latin, Retrospective forms of verbs of resultant state may be used to represent either a complete past event or a resultant state of affairs in the present, a usage which parallels the Bantu usage of stative verbs.

(ii) The form tuguzîre, without any internal modification tends to represent the past event, what we may call the aorist or Perfective usage of the Retrospective (cf. the preterits in (18) above). The form with internal modification, tu-áá-guzire, on the other hand, is designed to represent the resultant state (present reference in (18) above). In other words, the apparent purpose of the /-áá-/ morpheme is to call attention to the resultant state rather than to the completion of the event; as such, this /-áá-/ is a secondary or focussing morpheme, the main aspectual marker being 
the suffix /-ire/. Consequently, the extended form tuááguzire is normally used as the second verb in a compound, since this form emphasizes the Retrospective aspect. The form tuguzîre can, however, be found as the second form in a compound, for example, with an auxiliary in the Far Past: túkabá tuguziré emótoka 'we had bought a car (which we no longer have)', the auxiliary /ka-/ being the marker for the Far Past. It is understood in these forms that the resultant state holds only for the duration of the tense of the auxiliary, hence, the understanding that the car was possessed only in the Far Past and is no longer in the possession of the buyers. The form tuguzire in this position does not prolong the representation of the resultant state as does the extended form tuááguzire.

(iii) If the simple form tuguzîre is used to represent the resultant state (unusual with transitive verbs, but possible) rather than the past event that creates the state, it no longer represents the Near Past but a present state which is best translated by an English passive: 'we are bought, we have been bought'. Passive voice and Retrospective aspect universally share many features, since the patient (the subject of the passive voice) may also be part of the result or goal of a transitive verb. The result of a verb such as bake is a cake or some other product of the oven, not a cook or a baker. There are, in fact, forms in English, such as I am finished that are ambiguous between an active Retrospective and a Passive reading. There are also similar shifts in the use of the past participle, as in (19).

(19) a. The thief had climbed up, broken the window, and ransacked the house.

b. the broken window; * the broken thief

In (19a), broken is active in sense, predicated of the subject (thief) through the medium of the auxiliary had. If predicated directly of the noun, as in (19b), the same participle cannot be active, but can have only a passive sense.

We may consequently represent the relationship of the two Ruhaya forms that are unmarked for tense as Stage 1 forms, a subsystem separate from the marked tenses of Stage 2, as in Figure 2. In this subsystem, the prototypical base form (unmarked) is an Imperfective (placed above the line of time to indicate a proto-type),

Figure 2. The two chronogenetic stages of the Ruhaya verbal system.

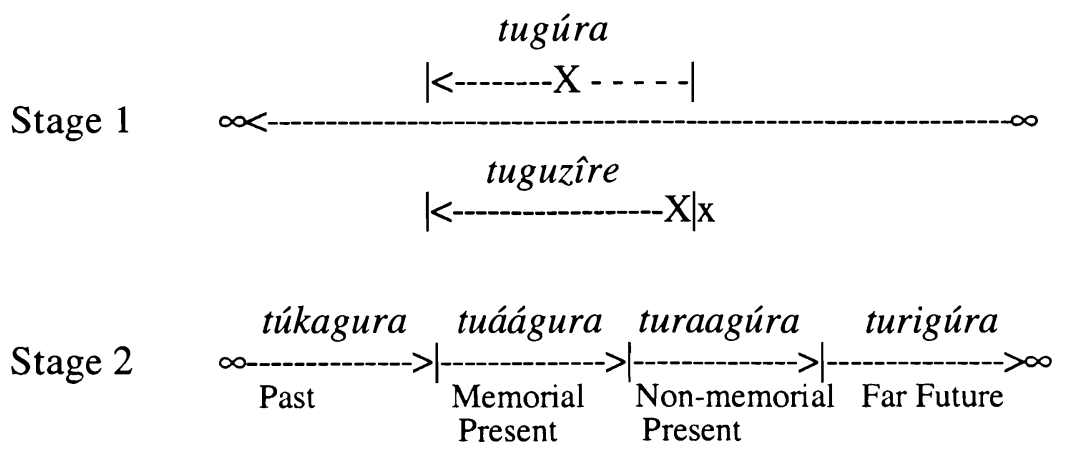


whereas the contrastive marked form is a Retrospective, a complete event seen from its result phase. If the result phase is ignored, the form simply represents a complete event, a variant that may be used as a preterit, in similar fashion to the Latin perfect, the French passé composé, and the German Perfekt.

5.2 The four contrastive tenses. The forms at Stage 1 are shown in Descending Time, whereas those of Stage 2 have been represented as being in Ascending Time, because, as single forms, they represent complete events, and in order to form the representation of an incomplete event, they must be combined with the Stage 1 form nitugúra: túkabá nitugura 'we were buying', for example, where túkabá is the auxiliary in the Far Past tense. The four tenses of Stage 2 have also been interpreted as Past, Memorial Present or Omega Present, Near Future or Alpha Present, and Far Future.

The terms alpha and omega are used by Guillaume to represent the last moments of the past (omega) and the first moments of the future (alpha). These moments are of importance in any representation of the present, and are important for the cognitive operations of consciousness, which may in turn become the basis for linguistic representations.

Just as spatial representation is based upon bodily experience [Johnson 1987] so that English up and down are based on our experience of gravity, temporal representation is based on fundamental and universal mental experiences shared by the whole animal kingdom: memory, perception, and imagination. Memory here means the retentive memory, the experience of the automatic reflex recording of the stream of consciousness, on which the notion of past is based (the past is that time which is coeval with memory). Perception means the ongoing reception of information supplied by the senses, which allows us to experience what we call the present. Imagination is an extrapolation from perception and memory that allows us to anticipate what is going to happen; it is the basis of our notion of future. Without imagination there would be no future.

Guillaume [e.g., 1964:59] used the phrase omega chronotype as a term for the most recent quantum of the past, and alpha chronotype for the most immediate quantum of the future. We may state the distinction in cognitive terms as follows:

$\alpha=$ the first moments of the immediate future, product of the operative imagination

$\omega=$ the last moments of the immediate past, stored in the retentive memory

These cognitive experiences are represented in different ways in different languages. Sometimes both $\alpha$ and $\omega$ moments are represented as elements of a present that separates past from future, as in Latin, French, Italian, Spanish, or Portuguese. Sometimes they are divided between past and non-past as in English, 
Danish, and Norwegian; 16 sometimes both are included in the non-past, as in German or Dutch [Hewson 1997:336-337].

In most of the Bantu languages that we have looked at (but not Swahili), the $\omega$ moments are represented by a distinct tense, which in cognitive terms may be called the memorial present (traditionally Near Past), and the $\alpha$ moments are represented by a distinct and separate tense (traditionally Near Future) that in cognitive terms may be called the non-memorial present. This Bantu division of the representation of present experience into two separate tenses, the Near Past and the Near Future, appears to be typologically distinctive.

The only remaining comment that needs to be made concerns the distribution of tugúra and tuguzîre. As elemental forms of the paradigm, they may be used alone, but they are rarely found in second position in compounds. Adjusted forms (ni-tugúra, tu-áá-guzire) are the ones that are normally found in second position, with a slightly adjusted meaning that stems from the markers /ni-/ and /-áá-/.

All the variant forms of Stage 1, whether morphologically adjusted or not, are distributionally distinct from the four tenses of Stage 2, which can never be used, even with morphological adjustments, in second position.

\section{Aspects Functioning as Tenses}

The analysis in $\S 5$, while it makes sense of the contrastive paradigmatic forms, does not immediately clarify the functional role of tuguzire as a Mid Past tense. Our claim that tuguzîre is a present Retrospective might appear, consequently, to be counter-intuitive. But a Retrospective aspect in the representation of the vast present of Stage 1 necessarily represents something that is complete; aspectual forms of the present can represent the past and the future just as successfully as tense forms: I have spoken, j'ai parlé, ich habe gesprochen are all marked for present, marked on the auxiliary, and the French and German forms can be used functionally as preterits.

Using aspectual forms in the function of tense is, in fact, as common as using a table knife as a screwdriver. Aorist, imperfect, and perfect were, in fact, classified, respectively, as "recent past, distant past, out of sight" in Vedic Sanskrit, by Pãnini, the great Sanskrit grammarian [Bubenik 1997:63]. In similar fashion, aspectual forms are frequently mingled with tense forms in Bantu traditional ways of representing time. As noted above, in Vedic Sanskrit the aorist (i.e., Perfective) was considered adyatana "in sight", hence "recent past". In Ruhaya, the /-ire/ form is similarly used, functionally, as a Near or Mid Past which is just beyond the Memorial Present, and distinct from the real past, which is totally divorced from the present, and then becomes, in usage, the Far Past (see Table 1).

The Memorial Present of Ruhaya (tuáágura) is a representation of the time that is coeval with the retentive memory (the memory of the stream of consciousness that is in the process of being recorded), or the working memory of consciousness.

16 Which explains the so-called "present reference" of the perfect in English and the Scandinavian languages [Hewson \& Bubenik 1997: 335-337]. (Adverbs of past time may not be used with such perfects: ${ }^{*}$ I have read that book yesterday). 
The retentive memory, or working memory, is a part of present experience: it is the memory that allows us to write or speak a sentence, or continue an explanation or a paragraph, without getting confused or losing our way. The conventions of the Ruhaya tense system are that this memory of the immediate past extends all the way back to the last sleep of the community, i.e., to the point where consciousness is interrupted by sleep. The referential scope of the Memorial Present is therefore "earlier today". The consciousness that immediately precedes "earlier today" is that of yesterday, which is the referential scope of the Near or Mid Past, which includes events that were completed before the Memorial Present and, consequently, viewed retrospectively from the Memorial Present.

An event seen retrospectively in the vast present of Stage 1 would necessarily be represented as a past event at Stage 2, to be surveyed retrospectively from the present. I have read that book means 'I have a present memory of a past event'. Such a past event necessarily took place before the present memory of it; its occurrence necessarily precedes the Memorial Present. In the Ruhaya system, therefore, a present Retrospective represents an event that necessarily precedes the Memorial present in which it is remembered (the "present memory of the past event"); this is exactly the normal sense attributed to tuguzîre, an event that took place in time before the Memorial Present.

\section{The Fourfold System of Aspects at Stage 1 in Ruhaya}

Just as there are four tense contrasts at Stage 2 in Ruhaya, two presents (memorial and non-memorial) and two non-presents (Past and Future), there are also four aspectual contrasts at Stage 1, with two simple forms (tugúra, tuguzîre), and two extended forms (tukiáágura, tuááguzire) that are based on the simple forms, as shown in two different formats in (20).

$\begin{array}{llll}\text { a. Imperfective } & \begin{array}{l}\text { Retrospective1 } \\ \text { tugúra }\end{array} & \begin{array}{l}\text { Persistive } \\ \text { tukiárérégura }\end{array} & \begin{array}{l}\text { Retrospective2 } \\ \text { tuááguzire }\end{array} \\ \text { b. } & \text { Unfocussed } & \text { Focussed } & \\ \text { Imperfective } & \text { tugúra } & \text { tukiáágura } & \\ \text { Retrospective } & \text { tuguzîre } & \text { tuááguzire }\end{array}$

This neat four-square paradigm (in which the Persistive could also be described as Imperfective 2), contains the answers to the remaining problematic questions expressed in (5) above.

First, it is clear from the distribution that the markers -kiáá- and -áá- cannot encode tense, although they occur in post subject position, since both of these forms are used freely as second elements in a compound, which would be impossible for forms that are marked contrastively for tense. One cannot have contrastive tenses in a compound: if both forms are tensed, they must either be of the same tense, or (as in most Bantu compounds) combinations of aspect and tense, that overlap and do not contrast (see Section 4 above, esp. fn. 11). The fact that the 
Persistive and Retrospective are augmented forms of the Imperfective and Perfective also leads us to the following proportion.

\section{(21) tugúra: tuguzîre :: tukiáágura : tuááguzire}

Here we have, in short, two forms of the Imperfective and two forms of the Retrospective. The Persistive looks back to an earlier stage of the Imperfect and affirms that what was ongoing then is still ongoing. Retrospective 2 similarly looks back to Retrospective 1 and affirms that the event that occurred there still has consequences; as we shall see in what follows, it is quite feasible that the morph /-áá-/ is the same element in both extended forms.

As we have seen, the ambivalence of the Retrospective (as in (18) above) is a quasi universal that Ruhaya chooses to exploit by explicit marking. In Latin, the distinction is not marked in the morphology, but shows up in the syntactic distribution, in what was called the Sequence of Tenses by the classical grammarians: when the Latin perfect is used in present reference, dependent clauses have primary tenses (e.g., present and future); where it is used in the function of preterit, dependent clauses have secondary marking (e.g., past tense forms). The ambivalence has led some scholars to treat the Latin perfect as two separate elements; this procedure is methodologically unacceptable, since no matter how irregular the paradigms, no Latin verb has two distinct morphological forms for the two different functions.

In this universal ambivalence of the Retrospective, we find the answer to our final query: why is it that there are two forms of the Retrospective (tuguzîre, tuááguzire)? This question is raised in (4), and the answer anticipated in a comment in 3.2, reworded and made explicit here as (22).

(22) Perfective and Retrospective representations are very similar, being separated merely by a threshold, hence their tendency to fall together historically, or for one form to be used in both functions.

The function of the marker -áá- in tuááguzire, consequently, is that of an adverbial focus marker that automatically and mechanically shifts the emphasis of the Retrospective from the event to its result phase, to its present reference. An adverb such as already has similar effects in English: I already did that = I have done that. Consequently, we have two contrasting aspectual forms, one, the bare form tuguzîre that is typically used to represent an event viewed retrospectively from the present, and the other, the extended form tuááguzire that is typically used to represent the result phase of the retrospective view. The most striking piece of evidence in support of this analysis is the Mid Past Retrospective from Table 1 that combines both forms: tubaire tuááguzire. Here the bare form of the auxiliary is used to establish a position in the recent past, and the extended form of the main verb to establish a Retrospective aspect. Even more striking is the existence of compounds of identical grammatical forms with stative verbs: tubaire tu-nagi-ire 'we were sleeping', where the auxiliary establishes the time of the event, and the main verb, as a bare form, marks the resultant state. 
This analysis of the Retrospective is supported by the other equation from the proportion in (21): the Imperfective and the Persistive are related in similar fashion. The Imperfective is simply the representation of an incomplete or ongoing event; the Persistive is a representation of an event that is still incomplete or ongoing. The English adverbs already and still share common features: already looks back to a point in the past; still represents a continuation from a point in the past.

It is quite probable, in fact, that the -áá- of -kiáá-, since it can, in fact, be left out in negative forms (e.g., ti-tu-ki(áá)-gura 'we are not still buying'), is the same element as the -áá- of tuááguzire. Both are, in a sense, retrospective: one looks back to an incomplete event (Persistive), and one looks back to a complete event (Retrospective). In the negative, it is redundant, of course, to represent the continuity of an event that did not, in fact, continue, especially if the negation is emphatic: 'I never did that again, I'm not doing that any more, I'll never do that again'.

\section{Conclusion}

We may represent the four aspects and the four tenses of Ruhaya in diagram form as in Figure 3, which is an expansion of Figure 2 above, based on the arguments in $\S 7$.

The basic structure of the four tense system of Stage 2 is binary. The first binary contrast is between the present and the non-present. In the present there is a binary contrast between the future and the past that parallels the immediate cognitive experiences of retentive memory and immediate imagination. In the nonpresent, by extrapolation, there is also a future and a past, traditionally described as the Far Future and the Far Past.

8.1 Principles and Practices. The principles, constraints, and procedures that have been practised in this analysis are as follows.

(23) Equal weight is given to grammatical meanings and to the morphological shapes that mark those meanings. The data of both morphology and semantics is deliberately respected. If a morpheme means one thing in one part of the paradigm, it is accepted that it means the same thing elsewhere, unless the contrary can be proven.

(24) The search from the beginning is a search for an underlying system, for a balanced set of contrasts that can be displayed in diagrams such as Figure 3. Such systems are not abstractions: they are mental constructs that are permanently stored in the subconscious of native speakers, accessible to use, but not to direct observation. Grammatical systems, in short, have distinctive patternings, just as do phonological systems, such as the triangular and quadrilateral patterns of vowel systems.

(25) Each grammatical system is a content system of meaningful contrasts that is marked by the regular morphological and distributional contrasts of the paradigm. 
Figure 3. The two chronogenetic stages of the Ruhaya verbal system (expanded)

Stage 1

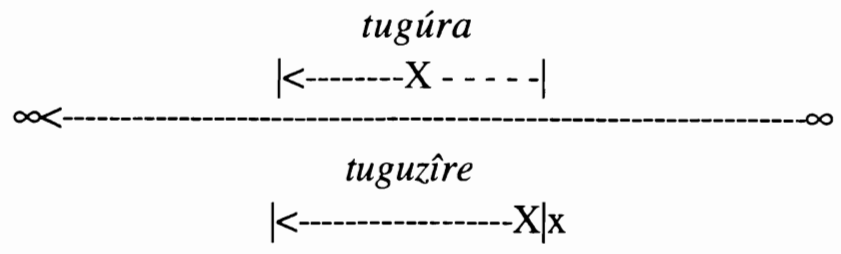

Stage 2

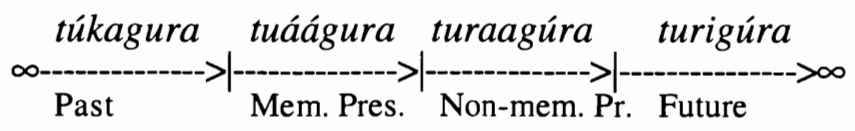

(i) Left pointing arrows represent Descending Time; right pointing arrows represent Ascending Time.

(ii) Aspectual contrasts are represented vertically, because they are con-trasts of Event Time. The prototypical form is given above the line of time, and the derived forms listed below in order of morphological complexity.

(iii) Tense contrasts are listed horizontally because they are contrasts of Universe Time.

(iv) $\mathrm{X}$ marks the position of the subject involved in the event; $\mathrm{x}$ marks a relative position of the same subject that may be the focus of a related form.

(v) Forms given are phonemic (except for tone marking): high vowels become glides when followed by a non-high vowel.

The role of the morphosyntax is to mark the content system which, by itself, is purely mental and not directly observable. It is indirectly observable (a) through the corresponding contrasts marked in the morphosyntax, and (b) through the distribution of the derived surface meanings in discourse.

(26) Although grammatical systems are primarily content systems, they cannot be separated from their morphological markers or from the data of their syntactic distribution. This is the correlation of (23) and (24).

(27) Grammatical systems are mental constructs, mental mechanisms for representing bodily and mental experience. Such mechanisms may be staged, i.e., they may have different interactive levels, with each level leading to a more complex representation. The universality of such staging is immediately observable in the 
vast data of derivation, as in the two stages of derivation that allow us to derive wonderfully from wonder or rethinking from think.

8.2 Questions of historical trajectory. Given the quasi-universality of certain kinds of aspectual distinctions, such as Imperfective, Perfective, and Retrospective (see 3.2 above), it often happens that if one of these is reinterpreted, levelled, or otherwise lost, a new form will be created to take its place. Elsewhere in Bantu languages, for example, the suffix *aga is a common marker for the Imperfective or Iterative, and *-ile a common marker for Perfective or Retrospective. Of these, Ruhaya has kept only *-ile, in the reflex -ire, the Imperfective being unmarked, and distinguished distributionally from the unmarked Performatives of Stage 2 by restricting the representation of Descending Time (of which the Imperfective is normally the unmarked member) to Stage 1, and the representation of Ascending Time (of which the unmarked member is the Performative), to Stage 2. The only fully functional aspectual suffix in Ruhaya is, therefore, -ire, since the reflex of *-aga is not used in the present and seems to have been distributionally restricted to the two forms in which it still occurs (see Table 1).

There is much interesting historical work to be done in tracing the loss or reinterpretation of the aspectual suffixes (i.e., synthetic aspect) of Bantu languages, and the development of compensating compound forms (i.e., analytic aspect) to represent aspectual distinctions. 


\section{REFERENCES}

Benveniste, Emile. 1965. "Le langage et l'expérience humaine." Diogène 51: 313. (Repr. in Benveniste 1966).

Benveniste, Emile. 1966. Problèmes de linguistique générale. Paris: Gallimard.

Botne, Robert. 1983. "The semantics of tense in Kinyarwanda." Studies in African Linguistics 14,3: 235-263.

Botne, Robert. 1986. "The temporal role of -ba and -li." Studies in African Linguistics 17,3: 303-317.

Botne, Robert. 1989. "The function of auxiliary -bá in Kinyarwanda." In Francis Jouannet (ed.), Modèles en tonologie (Kirundi et Kinyarwanda). Paris: CNRS. Pp. 247-256.

Bubenik, Vit. 1997. "The Verbal System of Vedic and Classical Sanskrit." In J. Hewson and V. Bubenik (eds.), pp. 67-81.

Byarushengo, Ernest R., Larry M. Hyman and Sarah Tenenbaum. 1976. "Tone, accent, and assertion in Haya." In Larry M. Hyman (ed.), Studies in Bantu Tonology (SCOPIL 3). Los Angeles: University of Southern California. Pp. 183-206.

Byarushengo, Ernest R., A. Durnati and Larry M. Hyman (eds). 1977. Haya Grammatical Structure (SCOPIL 6). Los Angeles: University of Southern California.

Clark, Herbert H. 1973. "Space, Time, Semantics, and the Child." In T. Moore (ed.), Cognitive Development and the Acquisition of Language. New York: Academic Press. Pp. 27-60.

Comrie, Bernard. 1976. Aspect. Cambridge: Cambridge Univ. Press.

Comrie, Bernard. 1985. Tense. Cambridge: Cambridge Univ. Press.

Contini-Morava, Ellen. 1989. Discourse Pragmatic and Semantic Categorization: the Case of Negations and Tense-Aspect with Special Reference to Swahili. Berlin: Mouton de Gruyter.

Dahl, Östen. 1985. Tense and Aspect Systems. Oxford: Blackwell.

Dalgish, Gerald M. 1977. "Past tense formation in (Oru)Haya." African Languages/Langues Africaines 3: 78-92. 
Fillmore, Charles J. 1975. Santa Cruz Lectures on Deixis, 1971. Bloomington: University of Indiana Linguistics Club.

Fleischman, Suzanne. 1982. "The Past and the Future: Are they 'coming' or 'going'?" Proceedings of the 8th Annual Meeting of the Berkeley Linguistics Society. Berkeley, CA: Berkeley Linguistics Society, Inc. Pp. 322-334.

Fletcher, Paul. 1985. "The Development of the Verb Phrase." In Paul Fletcher and Michael Graham (eds.), Language Acquisition. Cambridge: Cambridge University Press. Pp. 260-284.

Guillaume, Gustave. 1929/1965. Temps et verbe. Paris: Champion.

Guillaume, Gustave. 1933. "Immanence et transcendance dans la catégorie du verbe: Esquisse d'une thèorie psychologique de l'aspect." Journal de psychologie. Reprinted in Guillaume 1964: 46-58.

Guillaume, Gustave. 1937/1964. "Thèmes de présent et système des temps français." Journal de psychologie. Reprinted in Guillaume 1964: 59-72.

Guillaume, Gustave. 1945/1965. Architectonique du temps dans les langues classiques. Copenhagen: Munksgard. (Repr., Paris: Champion, 1965).

Guillaume, Gustave. 1951. "De la double action séparative du présent dans la représentation du temps." Mélanges Albert Dauzat. Paris: D'Artrey. (Reprinted in Guillaume 1964: 208-219).

Guillaume, Gustave. 1952. La langue, est-elle ou n'est-elle pas un système? Québec: Presses de l’Université Laval.

Guillaume, Gustave. 1964. Langage et science du langage (2nd ed. 1969). Québec: Presses de l’Université Laval.

Guillaume, Gustave. 1971. Leçons de linguistique. Vol. I: Structure sémologique et structure psychique de la langue française I. Paris: Klincksieck; Québec: Presses de l'Université Laval.

Guillaume, Gustave. 1971-2000. Leçons de linguistique. (13 volumes published so far). Québec: Presses de l'Université Laval.

Heine, Bernd. 1993. Auxiliaries: Cognitive Forces and Grammaticalization. New York \& Oxford: Oxford University Press.

Hewson, John. 1997. "Tense and Aspect in Modern Germanic." In J. Hewson and V. Bubenik, Pp. 331-350. 
Hewson, John and Vit Bubenik. 1997. Tense and Aspect in Indo-European Languages: Theory, Typology, Diachrony. Amsterdam \& Philadelphia: John Benjamins.

Hewson, John and Derek Nurse. 2001. "Chronogenetic Staging in the Swahili Verbal System." In B. Drinka and D. Nurse (eds.), African Language and Culture in Historical Perspective: Gedenkschrift für Edgar Polomé. General Linguistics 38: 77-110.

Hyman, Larry M. and Ernest Byarushengo. 1984. "A model of Haya tonology." In G. N. Clements and J. Goldsmith (eds.), Augmental Studies in Bantu Tone. Dordrecht, Holland \& Cinnaminson, U.S.A: Foris. Pp. 53-104.

Jakobson, Roman. 1968. Child Language, Aphasia, and Phonological Universals. The Hague: Mouton.

Jakobson, Roman. 1971. Studies in Child Language and Aphasia. The Hague: Mouton.

Jakobson, Roman. 1990. On Language. (Linda Waugh and Monique MonvilleBurston, eds.) Cambridge, MA: Harvard University Press.

Johnson, Marion R. 1980. "A Semantic Description of Temporal Reference in the Kikuyu Verb." Studies in African Linguistics 11/3: 269-320.

Johnson, Mark. 1987. The Body in the Mind. Chicago: University of Chicago Press.

Lakoff, George and Mark Johnson. 1980. Metaphors We Live By. Chicago: University of Chicago Press.

Muzale, Henry R.T. Forthcoming. A Reconstruction of the Proto-Rutara Tense/Aspect System. Cologne: Rüdiger Köppe. (Published version of the 1998 Ph.d. dissertation, Memorial University of Newfoundland).

Nurse, Derek. 1979. "Description of sample Bantu languages of Tanzania." (Chapter 1: Haya). African Languages/ Langues Africaines 5/1: 4-15.

Nurse, Derek and Henry Muzale. 1999. "Tense and Aspect in Great Lakes Bantu Languages." In J.-M. Hombert and L. M. Hyman (eds.), Recent Advances in Bantu Historical Linguistics. Stanford: CSLI. Pp. 517-544.

Saloné, Sukari. 1977. “Conditionals.” In Byarushengo et al. (eds). Pp. 149-159.

Taylor, C. 1959. A Simplified Runyankore-Rukiga-English and English-Runyankore-Rukiga Dictionary. Kampala: Eagle Press. 
Traugott, Elizabeth C. 1978. "On the Expression of Spatial-Temporal Relations in

Language.” In J. H. Greenberg (ed.), Universals of Human Language, vol. III. Palo Alto: Stanford Univ. Press. Pp. 369-400.

Valin, Roch. 1965. "Les aspects du verbe français." In Mélanges Rosetti. Bucharest: Editura Academiei Republicii Socialiste România. Pp. 967-975.

Valin, Roch. 1975. "The Aspects of the French Verb." [Translation of Valin 1965 by W. H. Hirtle] In W. H. Hirtle, Time, Aspect, and the Verb. Québec: Presses de l'Université Laval. Pp. 131-145.

Wald, Benji. 1997. "The 0 Tense Marker in the Decline of the Swahili Auxiliary Focus System." Afrikanistische Arbeitspapiere 51: 55-82.

Department of Linguistics

Memorial University of Newfoundland

St. John's, NF

Canada A1B 3X9

nurse@ roadrunner.nf.net

jhewson@mun.ca

hmuzale@ud.co.tz
[Received January 2001; accepted August 2001] 
Studies in African Linguistics

Volume 29, Number 2, Fall 2000

From the edge:

A sketch of Ongota, a dying language of Southwest Ethiopia

Graziano Savà and Mauro Tosco 
